\title{
Urinary Extracellular Vesicles Are a Novel Tool to Monitor Allograft Function in Kidney Transplantation: A Systematic Review
}

\author{
Liang Wu ${ }^{1,2, * \mathbb{C}}$, Karin Boer ${ }^{1}$, Wouter W. Woud ${ }^{1}$, Suwasin Udomkarnjananun ${ }^{1,3}$, Dennis A. Hesselink ${ }^{1} \mathbb{C}$ \\ and Carla C. Baan ${ }^{1}$ \\ 1 Erasmus MC Transplant Institute, Department of Internal Medicine, University Medical Center Rotterdam \\ Erasmus MC, Doctor Molewaterplein 40, 3015 GD Rotterdam, The Netherlands; \\ karin.boer@erasmusmc.nl (K.B.); w.woud@erasmusmc.nl (W.W.W.); \\ s.udomkarnjananun@erasmusmc.nl (S.U.); d.a.hesselink@erasmusmc.nl (D.A.H.); \\ c.c.baan@erasmusmc.nl (C.C.B.) \\ 2 Department of Nephrology, The First Affiliated Hospital of Shaoyang University, Shaoyang 422000, China \\ 3 Division of Nephrology, Department of Medicine, Faculty of Medicine, Chulalongkorn University and King \\ Chulalongkorn Memorial Hospital, 1873 Patumwan, Bangkok 10330, Thailand \\ * Correspondence: 1.wu.1@erasmusmc.nl; Tel.: +31-06-2214-5029
}

check for

updates

Citation: Wu, L.; Boer, K.; Woud, W.W.; Udomkarnjananun, S.; Hesselink, D.A.; Baan, C.C. Urinary Extracellular Vesicles Are a Novel Tool to Monitor Allograft Function in Kidney Transplantation: A Systematic Review. Int. J. Mol. Sci. 2021, 22, 10499. https://doi.org/10.3390/ ijms221910499

Academic Editor: Stefania Bruno

Received: 13 September 2021

Accepted: 23 September 2021

Published: 28 September 2021

Publisher's Note: MDPI stays neutral with regard to jurisdictional claims in published maps and institutional affiliations.

Copyright: (c) 2021 by the authors. Licensee MDPI, Basel, Switzerland. This article is an open access article distributed under the terms and conditions of the Creative Commons Attribution (CC BY) license (https:// creativecommons.org/licenses/by/ $4.0 /)$

\begin{abstract}
Extracellular vesicles (EVs) are nanoparticles that transmit molecules from releasing cells to target cells. Recent studies link urinary EVs (uEV) to diverse processes such as infection and rejection after kidney transplantation. This, and the unmet need for biomarkers diagnosing kidney transplant dysfunction, has led to the current high level of interest in $\mathrm{uEV}$. uEV provide non-intrusive access to local protein, DNA, and RNA analytics without invasive biopsy. To determine the added value of $\mathrm{uEV}$ measurements for detecting allograft dysfunction after kidney transplantation, we systematically included all related literature containing directly relevant information, with the addition of indirect evidence regarding urine or kidney injury without transplantation. According to their varying characteristics, uEV markers after transplantation could be categorized into kidney-specific, donorspecific, and immune response-related (IR-) markers. A few convincing studies have shown that kidney-specific markers (PODXL, ion cotransporters, SYT17, NGAL, and CD133) and IR-markers (CD3, multi-mRNA signatures, and viral miRNA) could diagnose rejection, BK virus-associated nephropathy, and calcineurin inhibitor nephrotoxicity after kidney transplantation. In addition, some indirect proof regarding donor-specific markers (donor-derived cell-free DNA) in urine has been demonstrated. Together, this literature review provides directions for exploring novel uEV markers' profiling complications after kidney transplantation.
\end{abstract}

Keywords: biomarker; donor-specific; graft dysfunction; immune response-related; kidney-specific; kidney transplantation; urinary extracellular vesicles

\section{Introduction}

Kidney transplantation provides better long-term survival and quality of life compared to dialysis [1]. In Europe and the United States of America, the current 5-year kidney allograft survival rate has reached $90 \%$ for living donor kidney transplant recipients (KTR), but about $50 \%$ of KTR still suffer allograft failure within 10 years of transplantation [2,3]. Kidney function is mostly assessed by serum creatinine ( $\mathrm{SCr}$ ) concentrations, estimated glomerular filtration rate (eGFR), and urine protein concentrations. However, for the early detection of kidney allograft dysfunction (including, among others, rejection, ischemiareperfusion injury $[\mathrm{I} / \mathrm{R}]$, recurrent primary kidney disease, drug-induced nephropathy, and infections), and establishing its cause, the value of these classical biomarkers is limited [4,5]. A for-cause biopsy is the current gold standard to establish the cause of kidney allograft dysfunction. However, a for-cause biopsy is costly and invasive, and this has fueled a 
continuing search for alternative biomarkers. Currently, non-invasive liquid biopsy and liquid biopsy-based biomarkers, e.g., cell-free DNA and extracellular vesicles (EVs), have shown an extremely high diagnostic value in various disorders, including malignancies, autoimmune diseases, organ dysfunction, and transplantation [6,7]. In this manuscript, we discuss how measurements of EVs could provide additional information about kidney function, thereby avoiding the need for an invasive biopsy [8].

Typical EVs have a lipid bilayer and range in diameter from 20 to $1000 \mathrm{~nm}$ and are generally classified into several subtypes due to different biogenesis pathways (Figure 1) [6,9]. The International Society for Extracellular Vesicles recommends the use of biochemical composition (surface markers, cargos) or parent cells to define and classify EVs [6]. EVs widely exist in various body fluids, e.g., plasma and urine, and can also be found in culture medium $[6,10,11]$.

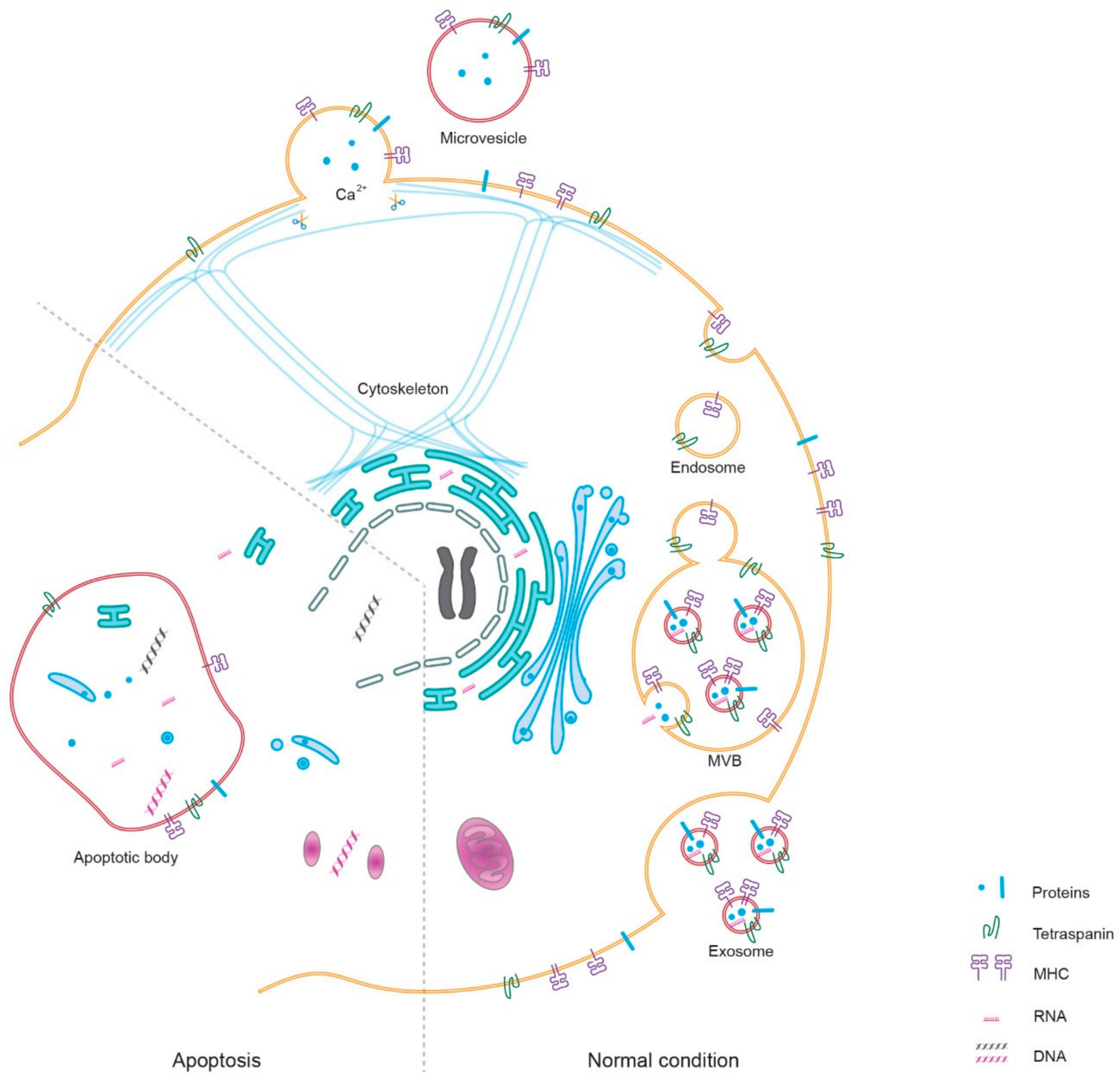

Figure 1. The biogenesis of extracellular vesicles (EVs). In normal conditions, exosomes are generated from the endosomal system and released by the intercellular multi-vesicle body (MVB). Microvesicles derive from the budding of plasma membrane due to the rearrangement of the cytoskeleton, with a high concentration of intracellular $\mathrm{Ca}^{2+}$ in the budding position. Apoptotic bodies are merely released during apoptosis. General markers such as proteins of the parental cell, tetraspanins, major histocompatibility complex (MHC), and RNA molecules can be found in all subtypes of EVs, but fragments of DNA and organelle are mostly assembled into apoptotic bodies during apoptosis. 
Urine is the most easily accessible, non-invasive body fluid for biomarker research on kidney dysfunction, including rejection. Urinary EVs $(\mathrm{uEV})$ might provide highly specific information for the kidney. For example, the proteins in $\mathrm{uEV}$ are predominantly $(99.96 \%)$ derived from the kidney and urinary tract [12]. Moreover, the changes in protein expression in kidneys are reliably assessed by the proteome of uEV [13].

Since several studies that enrolled different subjects and focused on diverse types of dysfunction have already explored the utility of $\mathrm{uEV}$ in kidney transplantation, our objective is to systematically summarize and investigate the diagnostic value of all types of biomarkers, such as protein, DNA, and RNA, in uEV during kidney transplantation. Due to the heterogeneity of available articles covered, with few of the same markers measured in $\mathrm{uEV}$, data synthesis and meta-analysis are currently not appropriate. In spite of this, we expect this review to promote the clinical application of uEV in kidney transplantation, providing more and specific information about kidney allograft function than traditional markers (such as SCr, eGFR) and thus potentially avoiding unnecessary invasive biopsies after transplantation.

\section{Materials and Methods}

\subsection{Data Sources and Searches}

This systematic review was in accordance with the 2020 Preferred Reporting Items for Systematic Reviews and Meta-Analyses (PRISMA) guidelines [14]. The literature search was conducted in the databases of PubMed and Scopus on 15 September 2021. All retrieved articles were also manually reviewed for studies in their references that could possibly be included.

For PubMed, we used the following terms: ("exosomes" [Mesh] OR "extracellular vesicles" [Mesh] OR "cell-derived microparticles" [Mesh]) AND "kidney transplantation" [Mesh] AND ("urine" [Subheading] OR "urinary" [All]). For Scopus, the following terms were used: TITLE-ABS-KEY (urine AND ((kidney AND transplantation) OR (kidney AND transplant)) AND ((extracellular AND vesicle) OR exosome OR ectosome OR microvesicle OR (apoptotic AND body))).

\subsection{Study Selection and Eligibility Criteria}

Retrospective and prospective studies that investigated the utility of uEV in kidney transplantation were included. Studies that only used animal models or cultured cells, or no uEV samples from kidney transplantation, were excluded. Only studies that showed a potential diagnostic value of markers in $\mathrm{uEV}$ during human kidney transplantation were included. Two authors (L.W. and S.U.) independently screened the titles and abstracts of the electronic citations, and full-text articles were retrieved for comprehensive review and independently rescreened. Disagreements were resolved through consensus and arbitration by K.B., D.H., and C.B.

\subsection{Data Extraction and Quality Assessment}

The following data were extracted from each study: author's name, year of publication, country of origin, outcome and numbers of KTR, timing of $\mathrm{uEV}$ measurement, method of $\mathrm{uEV}$ measurement, normalization method of urine dilution or concentration of $\mathrm{uEV}$, type of marker detected in $\mathrm{uEV}$, and the potential diagnostic information provided by $\mathrm{uEV}$ marker. Due to the high heterogeneity of included articles, quantitative synthesis of data was not appropriate. The assessment of reference was conducted with the Strengthening the Reporting of Observational Studies in Epidemiology (STROBE) statement for observational studies [15].

\section{Results}

In total, 73 published papers were retrieved. The flow diagram of the included and excluded articles is shown in Figure 2. After the exclusion of duplicated and irrelevant studies, 15 articles underwent data extraction. All included articles are shown with ex- 
tracted data in Table 1. The STROBE assessment for each study is shown in the Supplement (Table S1). As shown in Table 1, 5 studies enrolled fewer than 30 KTR in total. Overall, 6 studies attempted to normalize the dilution of urine or concentration of uEV, whilst 9 studies did not mention any efforts regarding normalization.

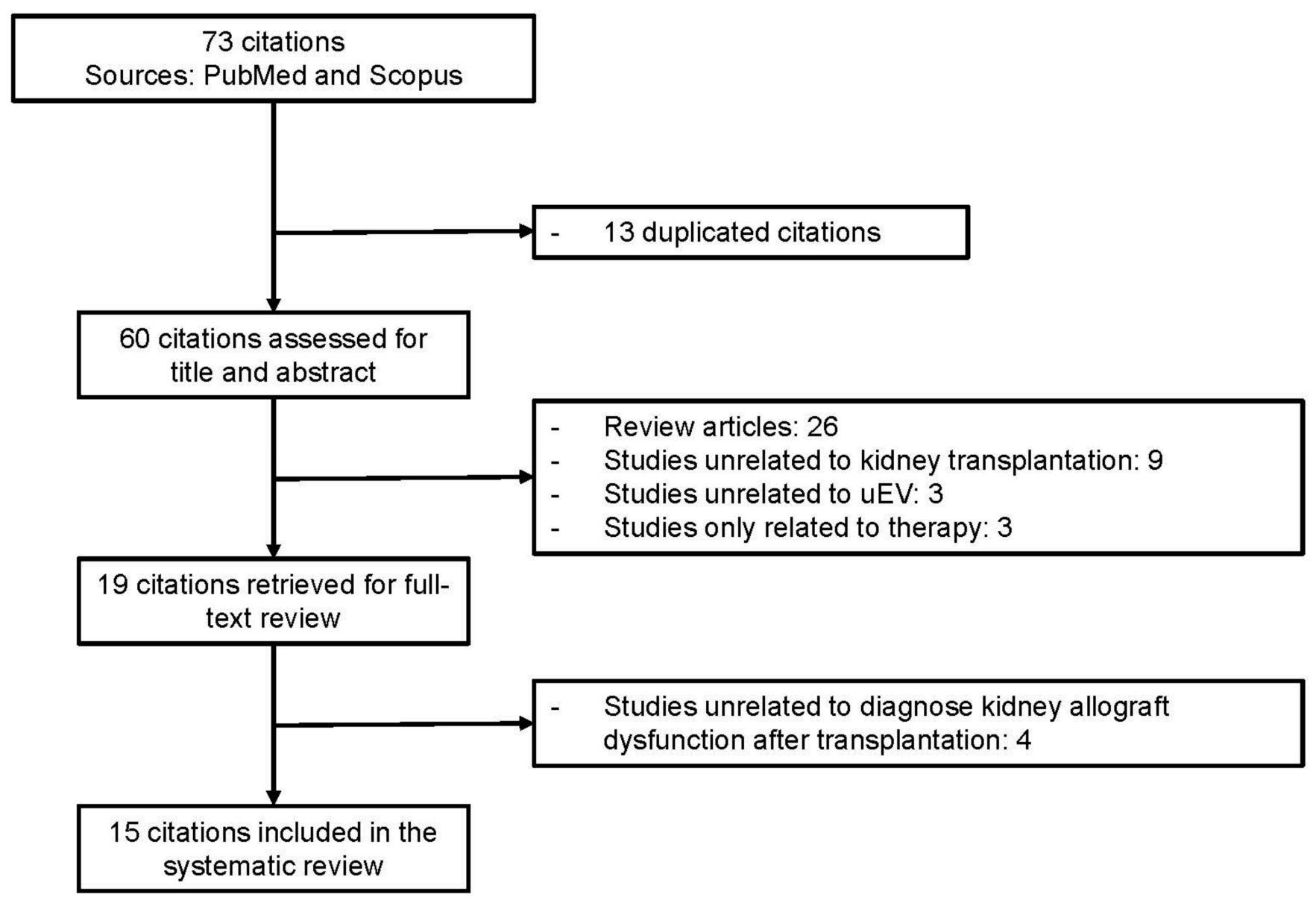

Figure 2. Flow diagram of the study selection. 
Table 1. Summary of studies reporting data of the diagnostic value of uEV in kidney transplantation.

\begin{tabular}{|c|c|c|c|c|c|c|c|c|}
\hline Authors & $\begin{array}{c}\text { Year of } \\
\text { Publication }\end{array}$ & $\begin{array}{l}\text { Country of } \\
\text { Origin }\end{array}$ & Outcomes and Population & $\begin{array}{l}\text { Timing of uEV } \\
\text { Measurement }\end{array}$ & Technique & Normalization & $\begin{array}{l}\text { Marker } \\
\text { in uEV }\end{array}$ & Diagnostic Information \\
\hline $\begin{array}{l}\text { Sonoda } \\
\text { et al. [16] }\end{array}$ & 2009 & Japan & $\begin{array}{c}\text { Early I/R after } \\
\text { transplantation }(n=1)\end{array}$ & $\begin{array}{l}\text { Day } 1 \text { before and } \\
\text { day } 2,6 \text { after } \\
\text { transplantation }\end{array}$ & $\begin{array}{l}\text { Immunoblot } \\
\text { analysis }\end{array}$ & No & AQP1 & $\begin{array}{l}\text { AQP1 was hardly detectable before transplantation and } \\
\text { significantly increased on day } 2 \text { after transplantation; } \\
\text { Decreased AQP1 on day } 6 \text { was likely caused by I/R, } \\
\text { according to findings in animal I/R models. }\end{array}$ \\
\hline $\begin{array}{l}\text { Pisitkun } \\
\text { et al. [17] }\end{array}$ & 2012 & USA & $\begin{array}{l}\text { Nonspecific findings } \\
\qquad(n=2) ; \\
\operatorname{TI}(n=7) \\
\text { TCMR }(n=6) \\
\text { AMR }(n=3)\end{array}$ & $\begin{array}{l}\text { Biopsy after } \\
\text { transplantation }\end{array}$ & $\begin{array}{l}\text { Large-scale } \\
\text { liquid } \\
\text { chromatography- } \\
\text { tandem mass } \\
\text { spectrometry }\end{array}$ & No & Proteome & $\begin{array}{l}\text { Compared to all KTR: } \\
\text { - } \quad \text { Cotransporter family showed higher expression in TI; } \\
\quad \text { Proteins related to epithelial cell differentiation showed } \\
\text { - } \quad \text { Proteins related to acute inflammatory response, or } \\
\text { antigen processing and presentation showed higher } \\
\text { expression in AMR. }\end{array}$ \\
\hline $\begin{array}{l}\text { Alvarez } \\
\text { et al. [18] }\end{array}$ & 2013 & Chile & $\begin{array}{c}\text { Non-DGF }(n=12) ; \\
\text { DGF }(n=3)\end{array}$ & $\begin{array}{l}\text { Day } 1,2,3 \text { after } \\
\text { transplantation }\end{array}$ & Western blotting & No & NGAL & $\begin{array}{l}\text { - Deceased donors showed higher levels of NGAL than } \\
\text { living donors; } \\
\text { The DGF group showed higher levels of NGAL than the } \\
\text { non-DGF group. }\end{array}$ \\
\hline $\begin{array}{l}\text { Dimuccio } \\
\text { et al. [19] }\end{array}$ & 2014 & Italy & $\begin{array}{l}\text { Early graft function } \\
\qquad(n=13) ; \\
\text { DGF }(n=12)\end{array}$ & $\begin{array}{l}\text { Hour 6, day } 1,7 \\
\quad 30 \text { after } \\
\text { transplantation }\end{array}$ & $\begin{array}{l}\text { Cytofluorimetric } \\
\quad \text { analysis \& } \\
\text { Western blotting }\end{array}$ & $\begin{array}{l}\text { Ratio of the } \\
\text { expression level in } \\
\text { CD133+ uEV and } \\
\text { in total uEV }\end{array}$ & CD133 & $\begin{array}{l}\text { The proportion of CD133+ uEVs was much higher in } \\
\text { healthy controls than ESRD patients; } \\
\text { CD133+ uEVs increased from day } 1 \text { to day } 30 \text { after } \\
\text { transplantation; } \\
\text { KTR with DGF showed a lower increase in CD133+uEV } \\
\text { at day } 1 \text {; } \\
\text { The lower level of CD133+uEV were associated with } \\
\text { worse graft vascular lesions. }\end{array}$ \\
\hline $\begin{array}{l}\text { Esteva- } \\
\text { Font et al. } \\
\quad[20]\end{array}$ & 2014 & Spain & $\begin{array}{c}\text { CsA-free }(n=8) \\
\text { CsA-treated }(n=39)\end{array}$ & $\begin{array}{l}1 \text { year after } \\
\text { transplantation }\end{array}$ & Immunoblotting & 24-h urine volume & $\begin{array}{l}\text { NCC \& } \\
\text { NKCC2 }\end{array}$ & $\begin{array}{l}\text { - NCC and NKCC2 was more highly expressed in the } \\
\text { CsA-treated group, whereas the } p \text {-values of all were } \\
\text { above } 0.05 \text { (NCC: } 0.1315 \text {, NKCC2 } 0.0542 \text { ); } \\
\text { NCC and NKCC2 were positively associated with the } \\
\text { blood concentration of CsA, with } p \text { values of } 0.0152 \text { and } \\
0.0497 \text {, respectively. }\end{array}$ \\
\hline $\begin{array}{l}\text { Sigdel } \\
\text { et al. [21] }\end{array}$ & 2015 & USA & $\begin{array}{l}\text { No rejection }(n=20) ; \\
\text { acute rejection }(n=10)\end{array}$ & $\begin{array}{l}\text { Biopsy after } \\
\text { transplantation }\end{array}$ & $\begin{array}{l}\text { Isobaric tags for } \\
\text { relative and } \\
\text { absolute } \\
\text { quantitation \& } \\
\text { nanoLC-MS/MS }\end{array}$ & No & Proteome & $\begin{array}{l}\text { DEFA5, CD5L, APOM, A2M, APOA2, PROS1, IGHM, } \\
\text { FGA, and FGB were significantly increased in the acute } \\
\text { rejection group. }\end{array}$ \\
\hline
\end{tabular}


Table 1. Cont.

\begin{tabular}{|c|c|c|c|c|c|c|c|c|}
\hline Authors & $\begin{array}{c}\text { Year of } \\
\text { Publication }\end{array}$ & $\begin{array}{l}\text { Country of } \\
\text { Origin }\end{array}$ & Outcomes and Population & $\begin{array}{l}\text { Timing of uEV } \\
\text { Measurement }\end{array}$ & Technique & Normalization & $\begin{array}{l}\text { Marker } \\
\text { in uEV }\end{array}$ & Diagnostic Information \\
\hline $\begin{array}{l}\text { Kim et al. } \\
\text { [22] }\end{array}$ & 2017 & $\begin{array}{l}\text { South } \\
\text { Korea }\end{array}$ & $\begin{array}{l}\text { Normal }(n=15) ; \\
\text { BKVN }(n=13) ; \\
\text { TCMR }(n=27) ; \\
\text { acute AMR }(n=9) ; \\
\text { CAMR }(n=16)\end{array}$ & $\begin{array}{l}\text { Biopsy after } \\
\text { transplantation }\end{array}$ & $\begin{array}{l}\text { Quantitative } \\
\text { real-time } \\
\text { polymerase } \\
\text { chain reaction }\end{array}$ & MiR-16 & $\begin{array}{l}\text { Viral mi- } \\
\text { croRNA }\end{array}$ & $\begin{array}{l}\text { Increased bkv-miR-B1-5p could diagnose BKVN, with } \\
\text { AUC value of } 0.989 \text { and cut-off value of } 5.9 \text { log10 } \\
\text { copies/mL (sensitivity } 100 \% \text {; specificity } 98.5 \%) ; \\
\text { Increased bkv-miR-B1-5p/miR-16 could diagnose BKVN, } \\
\text { with AUC value of } 0.985 \text { and cut-off value of } 1.2 \log 10 \\
\text { copies/mL (sensitivity } 100 \% \text {; specificity } 98.5 \% \text { ). }\end{array}$ \\
\hline $\begin{array}{l}\text { Park et al. } \\
\text { [23] }\end{array}$ & 2017 & USA & $\begin{array}{l}\text { No rejection }(n=22) \text {; } \\
\text { acute rejection }(n=22)\end{array}$ & $\begin{array}{l}\text { Biopsy after } \\
\text { transplantation }\end{array}$ & $\begin{array}{l}\text { Integrated } \\
\text { kidney exosome } \\
\text { analysis }\end{array}$ & No & CD3 & $\begin{array}{l}\text { Increased CD3 could diagnose acute rejection with AUC value } \\
\text { of } 0.911 \text { and cut-off value of } 0.298 \mu \mathrm{A} \text { (sensitivity } 92.8 \% \text {, } \\
\text { specificity } 87.5 \% \text { ) in discovery set, with AUC value of } 0.837 \text {. } \\
\text { (sensitivity } 63.6 \% \text {, specificity } 100 \% \text { ) in validation set. }\end{array}$ \\
\hline $\begin{array}{l}\text { Tutakhel } \\
\text { et al. [24] }\end{array}$ & 2017 & Netherlands & $\begin{array}{c}\text { CNIs-free }(n=13) \\
\text { CsA-treated }(n=9) \\
\text { Tacrolimus-treated }(n=23)\end{array}$ & $\begin{array}{l}\text { At least } \\
6 \text { months after } \\
\text { transplantation }\end{array}$ & Immunoblotting & $\begin{array}{l}\text { Ratio of } \\
\text { phosphorylated } \\
\text { NCC and } \\
\text { total NCC }\end{array}$ & NCC & $\begin{array}{l}\text { The expression of total NCC or phosphorylated NCC (Thr60) } \\
\text { in CNI-treated KTR was significantly higher. }\end{array}$ \\
\hline $\begin{array}{l}\text { Hinrichs } \\
\text { et al. [25] }\end{array}$ & 2018 & Denmark & $\begin{array}{l}\text { No albuminuria }(n=19) \\
\quad \text { albuminuria }(n=18)\end{array}$ & $\begin{array}{l}1 \text { year after } \\
\text { transplantation }\end{array}$ & Western blotting & Urinary creatinine & $\gamma \mathrm{ENaC}$ & $\begin{array}{l}\text { The expression of furin-cleaved } \gamma \mathrm{ENaC} \text { and protease-cleaved } \\
\gamma \mathrm{ENaC} \text { (not full-length } \gamma \mathrm{ENaC} \text { ) was significantly increased in } \\
\text { KTR with albuminuria. }\end{array}$ \\
\hline $\begin{array}{l}\text { Lim et al. } \\
\text { [26] }\end{array}$ & 2018 & $\begin{array}{l}\text { South } \\
\text { Korea }\end{array}$ & $\begin{array}{l}\text { Normal }(n=22) \\
\text { TCMR }(n=25)\end{array}$ & $\begin{array}{l}\text { Biopsy after } \\
\text { transplantation }\end{array}$ & $\begin{array}{l}\text { nanoLC-MS/MS } \\
\text { \& Western } \\
\text { blotting }\end{array}$ & No & Proteome & $\begin{array}{l}\text { - } \quad \text { APOA1, complement C3, HPX, PIGR, RBP4, etc. were } \\
\text { increased in acute TCMR; } \\
\text { - NEP, PROM1, LRP2, CD9, NAPSA, etc., were decreased } \\
\text { in TCMR. }\end{array}$ \\
\hline $\begin{array}{l}\text { Carreras- } \\
\text { Planella } \\
\text { et al. [27] }\end{array}$ & 2020 & Spain & $\begin{array}{l}\text { Normal }(n=7) \\
\text { CNIs nephrotoxicity }(n=5) \text {; } \\
\text { IFTA }(n=5)\end{array}$ & $\begin{array}{l}\text { Biopsy after } \\
\text { transplantation }\end{array}$ & $\begin{array}{c}\text { Mass } \\
\text { spectrometry }\end{array}$ & Ezrin & Proteome & $\begin{array}{l}\text { Compared to IFTA: } \\
\text { - Uroplakin family (UPK1A, UPK1B, UPK2, UPK3A), } \\
\text { RAB1B, etc. were more positive in CNIs nephrotoxity; } \\
\text { - Complement components (C3, C5, C7) etc. were more } \\
\text { negative in CNIs nephrotoxity. }\end{array}$ \\
\hline $\begin{array}{l}\text { Jung et al. } \\
\text { [28] }\end{array}$ & 2020 & $\begin{array}{l}\text { South } \\
\text { Korea }\end{array}$ & $\begin{array}{l}\text { Long-term graft survival } \\
\qquad(n=57) \\
\text { CAMR }(n=26)\end{array}$ & $\begin{array}{l}\text { Biopsy after } \\
\text { transplantation }\end{array}$ & $\begin{array}{l}\text { Liquid chromato- } \\
\text { graphy-mass } \\
\text { spectrometry }\end{array}$ & No & Proteome & $\begin{array}{l}\text { - } \quad \text { PODXL, MUC1, etc. were decreased in CAMR; } \\
\text { TTR, APOA1, HPX, complement C3, C4a, C4b, etc., were } \\
\text { increased in CAMR. }\end{array}$ \\
\hline $\begin{array}{l}\text { Takada } \\
\text { et al. [29] }\end{array}$ & 2020 & Japan & $\begin{array}{l}\text { Normal }(n=20) ; \\
\text { IFTA }(n=19) ; \\
\text { CNIs nephrotoxicity } \\
(n=17) ; \\
\text { CAMR }(n=22)\end{array}$ & $\begin{array}{l}\text { Biopsy after } \\
\text { transplantation }\end{array}$ & Western blotting & CD9 & SYT17 & $\begin{array}{l}\text { - The ratio of SYT17/CD9 could distinguish CAMR from } \\
\text { other groups, with AUC value of } 0.82 \text { and cut-off value } \\
\text { of } 0.42 \text { (sensitivity } 77 \% \text {; specificity } 87 \% \text { ) }\end{array}$ \\
\hline
\end{tabular}


Table 1. Cont.

\begin{tabular}{|c|c|c|c|c|c|c|c|c|}
\hline Authors & $\begin{array}{c}\text { Year of } \\
\text { Publication }\end{array}$ & $\begin{array}{c}\text { Country of } \\
\text { Origin }\end{array}$ & Outcomes and Population & $\begin{array}{l}\text { Timing of uEV } \\
\text { Measurement }\end{array}$ & Technique & Normalization & $\begin{array}{l}\text { Marker } \\
\text { in uEV }\end{array}$ & Diagnostic Information \\
\hline $\begin{array}{c}\text { Fekih et al. } \\
\quad[8]\end{array}$ & 2021 & USA & $\begin{array}{l}\text { No rejection }(n=133) ; \\
\text { acute } \operatorname{AMR}(n=8) ; \\
\text { CAMR }(n=16) ; \\
\text { TCMR }(n=35) ; \\
\text { borderline TCMR }(n=23) ; \\
\quad \operatorname{BKVN~}(n=5)\end{array}$ & $\begin{array}{l}\text { Biopsy after } \\
\text { transplantation }\end{array}$ & $\begin{array}{l}\text { Quantitative } \\
\text { real-time } \\
\text { polymerase } \\
\text { chain reaction }\end{array}$ & No & $\begin{array}{l}\text { Messenger } \\
\text { RNA }\end{array}$ & $\begin{array}{l}\text { - } 15 \text { mRNA (CXCL11, CD74, IL32, etc.) could discriminate } \\
\text { rejection from non-rejection, with the AUC value of } 0.93 \\
\text { (sensitivity 84.7\%; specificity 94\%); } \\
\text { - } 5 \text { mRNA (CD74, complement C3, CXCL11, CD44, and } \\
\text { IFNAR2) could distinguish TCMR from ABMR, with } \\
\text { AUC value of } 0.87 \text { (sensitivity } 87.5 \% \text {; specificity } 82.9 \% \text { ). }\end{array}$ \\
\hline
\end{tabular}

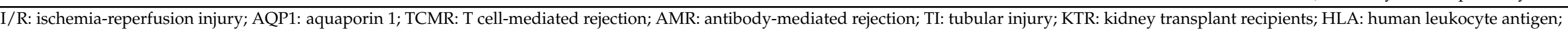



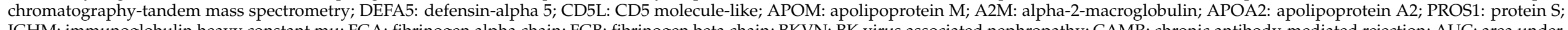



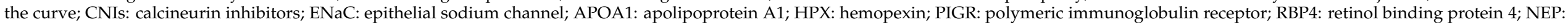

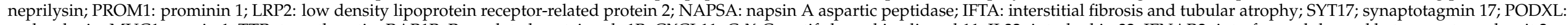

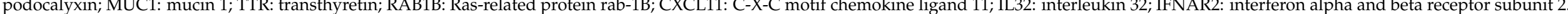




\section{Discussion}

Due to their different characteristics, we classify the diagnostic markers in uEV into three subtypes: (1) kidney-specific, (2) donor-specific, and (3) immune response-related (IR-) markers, thereby helping an understanding of their intrinsic biogenesis and properties during kidney transplantation (Figure 3). In addition, some important findings or clues that are not included in Table 1 are introduced in this review to help highlight the directions for future studies.

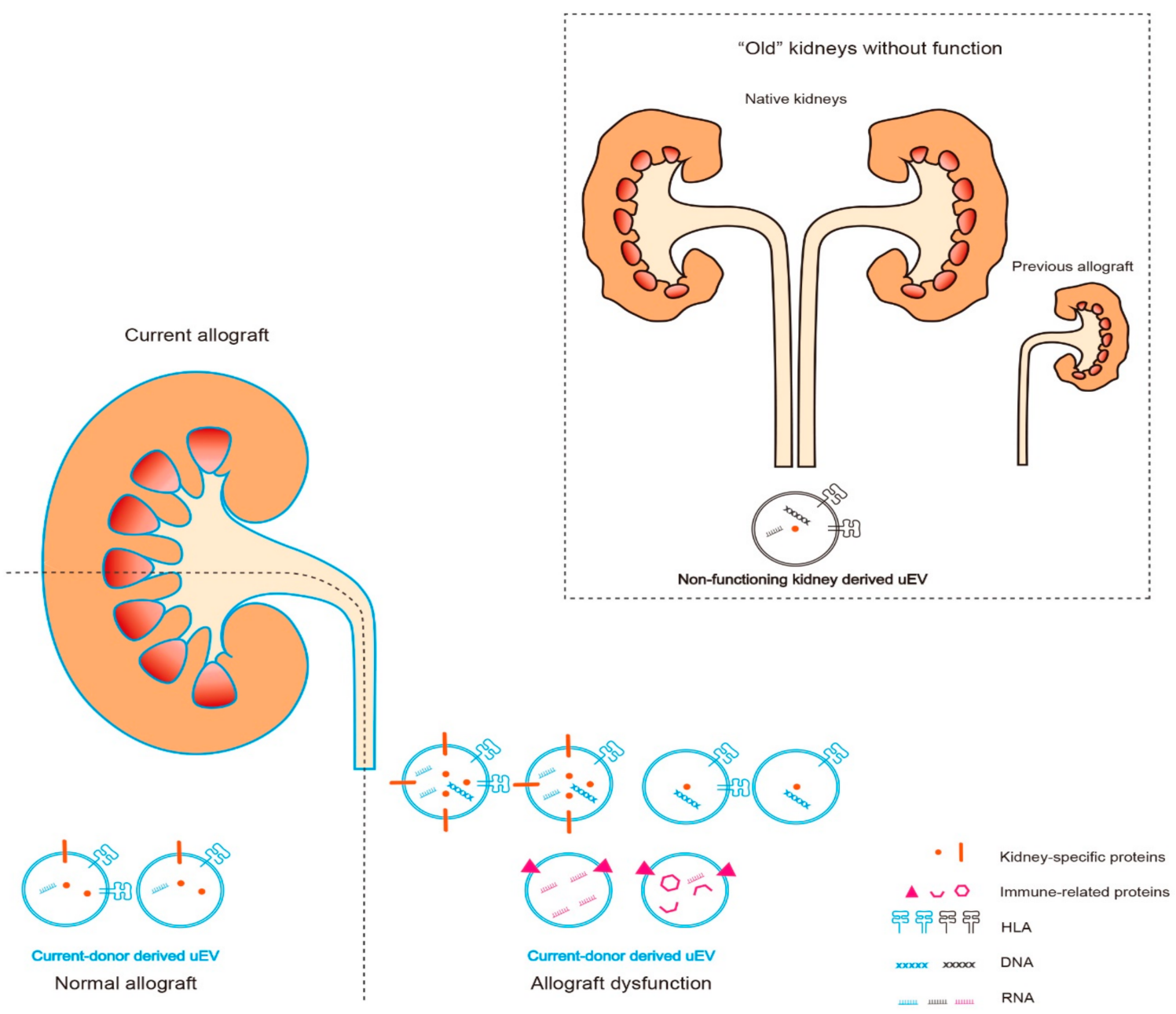

Figure 3. Urinary extracellular vesicles (uEV) in kidney transplantation. The "old" kidney/non-functioning kidney-derived vesicles, human leukocyte antigen (HLA), DNA, and RNA are denoted in black. Current-donor-derived vesicles, HLA, DNA, and RNA, are denoted in blue. Kidney-specific proteins are denoted in orange, and immune-related (including viral molecules) are denoted in pink. The "old" kidneys, including recipient native kidneys and previous kidney allograft, might generate fewer $\mathrm{uEV}$ than the currently functional kidney allograft. During allograft dysfunction, the population of $\mathrm{uEV}$ and the expression of markers in $\mathrm{uEV}$ would be different from those in normal condition.

Kidney-specific markers are of great value in studying kidney allograft function and could reflect minimal changes, such as age-associated changes of the kidney in living donors [30-32]. Donor-specific markers could be identified by human leukocyte antigen (HLA) or specific gene sequences in nucleic acid cargos, according to differences in the genetic make-up between donor and recipient. Hence, donor-specific markers in uEV might have the highest specificity for a current allograft, although no direct evidence has been forthcoming as yet. Immune reactions are strongly associated with the release of $\mathrm{uEV}$, which infiltrate immune cells or pathogen-containing cells in the kidney allograft, and IRmarkers in $\mathrm{uEV}$ can provide specific information during rejection and infection [33-35]. 


\subsection{Kidney Specific Markers}

\subsubsection{The Biogenesis of Kidney Specific Markers}

The current functioning kidney should be the major derivation of uEV because "old" kidneys, i.e., the native kidneys of the recipient, and those from previous donors, have little functionality due to barely integrated nephrons, although these might generate a small number of uEV (Figure 3).

In healthy conditions, kidney-specific proteins, e.g., aquaporin-1 (AQP1), aquaporin2 (AQP2), $\mathrm{Na}-\mathrm{Cl}$ cotransporter (NCC), Na-K-Cl cotransporter 2 (NKCC2), and PODXL, show high abundance in uEV [36,37]. During low kidney functionality, decreased release of uEV-AQP1 and uEV-AQP2 effectively detect GFR in G4 and G5 categories (KIDIGO guidelines) with a high area under the curve (AUC) value of 0.945 in the receiver operator characteristics curve analysis [38]. UEV-AQP1 has an extremely low level (not visible on Western blot) in patients with end-stage renal disease (ESRD) but shows a small increase after kidney transplantation [16,39]. Before transplantation, uEV-AQP2 is also barely detectable in KTR but increases significantly post-transplant [39]. Therefore, these kidneyspecific markers within $\mathrm{uEV}$ might be mostly and specifically excreted by the functional kidney allograft.

\subsubsection{The Diagnostic Potential of Kidney Specific Markers}

Compared to uEV-AQP2, the lower increase of uEV-AQP1 might be associated with early I/R [16]. Sonoda et al. set up an I/R rat model and found that decreased uEV-AQP1 occurred from $6 \mathrm{~h}$ to $96 \mathrm{~h}$ after an I/R operation compared to the sham group [16]. The decreased expression level of uEV-AQP1 was not associated with AQP1 expression in kidney tissue and the total protein in the $\mathrm{uEV}$, and so might be caused by the reduced excretion of AQP1 into the uEV [16]. The authors also found that uEV-AQP1 showed no association with proteinuria in patients with nephropathy, suggesting a specific diagnostic value of $\mathrm{uEV}$-AQP1 for I/R [16].

Pisitkun et al. reported a proteomic study that found elevated expression of renal cotransporters in $\mathrm{UEV}$ of KTR with tubular injury when compared to KTR overall [17] (Table 1). Elevated uEV-NCC and uEV-NKCC2 were discovered in KTR treated with calcineurin inhibitors (CNIs), including cyclosporine A (CsA) and tacrolimus, compared to CNI-free subjects $[20,24]$. In CsA recipients, uEV-NCC and uEV-NKCC2 showed strong correlations with CsA blood concentration, synchronously indicating CsA nephrotoxicity [20]. Moreover, after kidney transplantation, proteinuria had positive correlations with the glycosylated $\gamma \mathrm{ENaC}$ and furin-cleaved $\gamma \mathrm{ENaC}$ in $\mathrm{uEV}$ [25].

A recent $\mathrm{uEV-proteomic} \mathrm{study} \mathrm{demonstrated} \mathrm{that} \mathrm{PODXL} \mathrm{was} \mathrm{one} \mathrm{of} \mathrm{the} \mathrm{top} 10$ highly expressed proteins in small uEV of KTR with no early graft dysfunction [37]. Compared to KTR with stable allograft function, KTR with acute T cell-mediated rejection (TCMR) showed significantly decreased PODXL in uEV [26]. In KTR with chronic antibodymediated rejection (CAMR) and severely declined kidney function (mean SCr $3.6 \mathrm{mg} / \mathrm{dL}$ ), PODXL was also one of the most decreased proteins in uEV [28].

CD133 is highly expressed in progenitor-like cells of nephrons that release CD133+ $\mathrm{uEV}$, indicating proliferation in healthy subjects or recovery after injury $[19,40]$. In the urine of ESRD patients, CD133+ uEV was hardly detectable but was significantly increased on day 7 after kidney transplantation. A smaller increase compared to KTR with early allograft function might indicate delayed graft function (DGF) due to vascular lesion [19] (Table 1).

Synaptotagmin-17 (SYT17) is also specifically and highly expressed in the kidney. After kidney transplantation, the expression level of SYT17 in urinary exosomes was specifically elevated during CAMR compared to that in normal conditions, renal tubulointerstitial lesions, or CsA nephrotoxicity [29] (Table 1). The general tetraspanin marker CD9 was used to set up a normalization of urine dilution and showed that SYT17/CD9 could diagnose CAMR with a high AUC value of 0.82 . 
Neutrophil gelatinase-associated lipocalin (NGAL) is a typical kidney-specific marker for kidney injury. In the urinary exosomes from KTR, the deceased donor group showed a significantly higher level of NGAL than the living donor group 3 days after transplantation [18]. KTR who developed DGF also showed much higher urinary exosomal NGAL than those with no DGF [18] (Table 1).

According to these previous findings, we speculate that the expression of kidneyspecific proteins in uEV might share some common characteristics during kidney transplantation: (1) have a detectable and stable level in healthy subjects, (2) become barely detectable during ESRD due to few surviving parent cells in the "old" kidneys, (3) increase to a higher level than the ESRD period after kidney transplantation depending on the quality of allograft kidney, (4) temporarily show an increase or decrease during different types of kidney injury, (5) become barely detectable when the KTR develops ESRD again after serious or multiple kidney injury.

\subsection{Donor Specific Markers}

\subsubsection{HLA}

A proteomics study first reported that HLA-A, -B, -DRA, -DRB3 could indeed be measured in urinary exosomes from healthy individuals [41]. Park et al. used magnetic beads to catch T cell-derived $\mathrm{UEV}$ and found that HLA-ABC showed abundant expression in these $\mathrm{uEV}$ [23]. The urinary exosome also contains other subtypes / precursors of HLA, including the HLA-B, -DMA, -DMB, -DRA, and -A1 alpha chain, that were shown to be elevated in KTR with antibody-mediated rejection (AMR), compared to those with no AMR [17]. However, the quantity of HLA subclasses in UEV might be variable [42]. For instance, in podocyte vesicle-enriched urinary samples, HLA-B41,-B54,-B59 showed higher expression levels than HLA-A3, -A24, -A29, and HLA class II molecules had lower expression levels than those of HLA class I [42]. Donor-specific uEV measurements based on HLA mismatch might be hindered by the variable expression of HLA. To arrive at good and reliable measurements, we suggest that uEV should be isolated or concentrated from the urine before uEV-HLA analysis.

\subsubsection{Cell-Free DNA}

In addition to cell surface $\mathrm{uEV}$ markers, intra $\mathrm{uEV}$ markers are also of importance in kidney transplantation. Cell-free DNA (cf-DNA) represents a diagnostic marker for allograft dysfunction for several years, with donor-specific genetic sequences defining donor-derived cell-free (dd-cfDNA) [43,44]. For example, single nucleotide polymorphisms and InDels (genetic insertions or deletions) could be used to identify dd-cfDNA $[45,46]$.

DNA is abundant in apoptotic bodies derived from damaged cells, possibly explained by nuclear and mitochondrial fragmentation [47,48] (Figure 1). Intracellular stress could also promote chromosomal DNA and mitochondrial DNA (mtDNA) assembling into other subtypes of EV [49]. Fernando and colleagues found that 93\% plasma cf-DNA was localized in plasma exosomes [50]. Currently, there is limited research on cf-DNA or dd-cfDNA in $\mathrm{uEV}$, but $\mathrm{uEV}$ as a derivation or localization of urinary cf-DNA in cell-free urine samples could be considered. A previous study found that, compared to KTR with normal eGFR, dd-cfDNA in urine was significantly elevated in KTR with acute and chronic rejection and BK virus-associated nephropathy (BKVN) [51].

$\mathrm{uEV}$-mtDNA is an interesting subtype of cf-DNA in uEV, especially in those KTR with pre-transplant diabetes. A cohort study showed that, despite strict glycemic control, KTR with pre-transplant diabetes still showed a high incidence $(47.7 \%)$ of recurrent diabetic nephropathy (DN) 5 years after transplant [52]. In urinary exosomes, mtDNA was significantly decreased in patients with $\mathrm{DN}$ ( $36 \pm 18$ copies/ng) in contrast to healthy subjects (432 \pm 147 copies/ng) [53]. In urine, mtDNA had an inverse association with elevated eGFR during DN [54]. These findings corresponded, implying that donor-specific mtDNA might represent a potential marker in $\mathrm{uEV}$ for recurrent $\mathrm{DN}$. 


\subsection{Immune Response-Related Markers in $u E V$}

\subsubsection{Proteins}

Classical protein markers for leukocytes and $\mathrm{T}$ cells are detectable in $\mathrm{uEV}$, but we should be aware that common immune-related markers, such as CD3 and CD45, in uEV might barely distinguish rejection from other types of immune-related allograft dysfunction. $\mathrm{CD} 3+\mathrm{uEV}$ show strong positive correlations with kidney allograft rejection [23]. However, in renal tissue, CD3+ EVs and CD45+ EVs are also significantly elevated in hypertensionrelated kidney injury [55]. Moreover, CD3+ T cells markedly infiltrate renal tubules and interstitium during DN, leading to chronic inflammation [56].

In contrast, the complement components may provide more specific information. In $\mathrm{uEV}$, complement components 3 (C3), C4-a, C4-b were significantly increased in KTR with CAMR, compared with recipients with long-term graft survival [28]. C3 also showed the second highest correlation with TCMR among 63 overexpressed proteins in the $\mathrm{uEV}$ from KTR [26]. In addition, the overexpression of $\mathrm{C} 1 \mathrm{q}$ subcomponent subunit $\mathrm{B}$ and $\mathrm{C} 1 \mathrm{r}$ in $\mathrm{uEV}$ was strongly correlated with decreased GFR in the first year after kidney transplantation [37]. During CNI nephrotoxicity, a condition of immunosuppression, the levels of complement factors C3, C5, C7, C9 in uEV of KTR were significantly lower compared to KTR with interstitial fibrosis and tubular atrophy (IFTA), although only 17 KTR were enrolled [27]. These findings imply that the uEV-complement might be specifically correlated with the host immune response, especially rejection.

In uEV, defensin-alpha 5, chloride channel accessory 1, apolipoprotein A-2, CD5 molecule-like, alpha-2-macroglobulin, protein $\mathrm{S}$, immunoglobulin heavy constant $\mathrm{mu}$, and the heat shock protein family were all elevated in KTR with acute rejection in contrast to non-rejection patients $[17,21]$. Compared to KTR with stable kidney function, hemopexin and apolipoprotein A-1 in uEV were both significantly increased in KTR with CAMR [28] or acute TCMR [26]. In addition, the polymeric immunoglobulin receptor in uEV was significantly increased in TCMR but slightly decreased in CAMR, which might help distinguish CAMR from TCMR $[26,28]$.

\subsubsection{RNA}

$\mathrm{uEV}$ represent a major localization of cell-free RNA in the urine due to the membrane protection from RNase [56,57]. In 2013, Crescitelli et al. first demonstrated RNA profiles in subtypes of EV [58]. They found that RNA was primarily assembled into exosomes and apoptotic bodies, not into microvesicles, and cell injury could promote this assembly (Figure 1) [58]. uEV immune-related messenger RNA (mRNA) showed a strong association with kidney allograft dysfunction, especially rejection and viral infection [8]. Micro RNA (miRNA) - that has clear correlations with the immune response-could also be found in uEV [59].

Recently, Fekih et al. reported that a multi-mRNA signature in uEV could discriminate 59 KTR with biopsy-proven acute rejection from those without rejection [8]. In uEV, a signature consisting of 15 different mRNA could diagnose rejection with a high AUC value of 0.93. In addition, the mRNA signature of C3-CD44-CD74-CD119-CXCL11 was significantly higher in AMR compared to TCMR [8]. As for chronic inflammation, the elevated CCL21mRNA in uEV might be a candidate biomarker for early recurrent diabetic nephropathy based on a recent study. In uEV, CCL21-mRNA showed a high AUC value of 0.89 for distinguishing diabetic patients with early biopsy-proven DN (eGFR $>90 \mathrm{~mL} / \mathrm{min} / 1.73 \mathrm{~m}^{2}$ ) from those without DN [56]. These are novel findings in the uEV field and should be further confirmed in future studies with more KTR samples.

miRNA is clearly associated with the immune response during kidney transplantation [60], and the miRNome of uEV has been well demonstrated before transplantation. In 2013, Gildea and team first reported a miRNome of urinary exosome where less than 21 serum-exosome-derived miRNA were detected in a total measured 1898 miRNA, suggesting that uEV-miRNA might derive mostly from the kidney or urinary tract [61]. In 2018, another miRNome study of $\mathrm{uEV}$ from donors reported that the profile of miRNA did not 
discriminate between living donors and deceased donors before transplantation [62]. The role of miRNA in uEV after kidney transplantation is not yet fully explored as currently most diagnostic findings of miRNA are based on human kidney disease before transplantation [59], cultured kidney cell [30,63], animal model [63,64], or urine sample only with no $\mathrm{uEV}$ isolation or detection [57,65-68], rather than on uEV from KTR after transplantation.

For example, uEV-miR-200 and uEV-miR-29 were positively correlated with eGFR and renal fibrosis during chronic kidney disease [59], which should be noticed in KTR with chronic kidney injury. During chronic injury, the damaged tubular epithelia released increased miR-21-enriched uEV that further exacerbate renal fibrosis [63], suggesting that uEV-miRNA might also be a crucial modulator in the damaged kidney allograft.

Some studies focused on the miRNA in the urine and not on uEV. However, uEVmiRNA might be a major localization/derivation of total urinary miRNA [57], where urinary miR-21 is especially highlighted during kidney transplantation. Compared to a group with normal function, KTR with IFTA showed upregulated urinary miR-21 [65], which corresponded to elevated uEV-miR-21 during chronic kidney disease [63]. Khalid et al. reported that elevated urinary miR-21 could predict DGF with an AUC between 0.75 to 0.94 [66]. In the first urine from KTR after transplantation, miR-21 was elevated at least 5-fold in deceased donors with DGF in contrast to deceased donors with no DGF ( $p$-value $>0.001$ and $<0.05)$, or living donors with no DGF ( $p$-value $<0.001)$ [66]. In addition, deregulated urinary miR-142-3p and miR-200b were found in KTR with IFTA [67]. Urinary miR-210 was strongly deregulated in KTR, with acute TCMR predicting a decline in GFR in the first year after transplantation [68].

\subsubsection{Viral Infection Related Markers}

Viral components can be assembled into the uEV after transplantation when the kidney allograft is infected by a virus hampering kidney function (Figure 3). BK virus nephropathy is a common outcome of viral infection after kidney transplantation [69]. In uEV, Kim et al. found that elevated viral miR-B1-5p, miR-B1-3p, and recipient miR-16 could precisely diagnose BKVN, and the uEV-miR-B1-5p showed a high AUC value of 0.989 [22]. Their findings partially corresponded with another study, where miR-B1-5p and miR-B1-3p were also significantly increased in KTR with BKVN, in contrast to those with no BKVN. However, kidney biopsy tissues, not $\mathrm{uEV}$, were used in this study [70].

Coronavirus disease 2019 (COVID-19) related nephropathy is another recent important viral nephropathy during kidney transplantation [71]. Due to immunosuppression, KTR might more likely develop severe COVID-19 than the general population [71,72]. In about a third of patients with COVID-19, the severe acute respiratory syndrome coronavirus 2 (SARS-CoV-2) could infect kidney tissue and lead to acute kidney injury [73]. SARS-CoV-2 is hardly detected in the urine [74], but SARS-CoV-2 infected kidney cells might release more $\mathrm{uEV}$ with specific markers. In vitro, the spike protein of SARS-CoV-2 could promote embryonic kidney cells (HEK 293) to release EVs with higher expression of miR-590-3p and miR-148a [75].

\subsection{Challenges and Future Perspective}

$\mathrm{uEV}$ have potential as non-invasive biomarkers to monitor kidney allograft dysfunction and to establish its cause. However, there are still two major blanks to be filled, with potential for new and interesting directions of study: (1) HLA and DNA have not yet been shown to be "donor-specific" in uEV, based on any evidence of donor-recipient mismatch; (2) urinary miRNA is of great diagnostic value for kidney allograft dysfunction, whereas the characteristics of $\mathrm{uEV}$-miRNA in kidney transplantation are unknown. In addition, tacrolimus is currently more widely used than CsA, so future CNI-related research should also focus on tacrolimus-related complications.

At present, the difficulty with $\mathrm{uEV}$ studies is that, although available research explores interesting diagnostic markers in $\mathrm{uEV}$, these studies are not all of the same quality. Challenges relating to this: 
1. many studies omit the necessity of normalizing urine dilution (Table 1);

2. some studies merely detect the expression level of markers in the total $\mathrm{uEV}$, rather than measure a particular "marker"-positive population of uEV;

3. some clinical research is limited by small numbers of samples or a poor or non-existent description regarding the clinical properties of enrolled patients;

4. the significant proteomic changes of $\mathrm{uEV}$ in some types of kidney dysfunction have been well studied, whereas the diagnostic accuracy (sensitivity, specificity, and AUC) of these changes is still unclear.

We propose the following steps to move uEV research forward:

1. The normalization of $\mathrm{uEV}$ concentration/urine dilution is necessary in the research protocol. According to the newest guidelines published by the Urine Task Force of the International Society for Extracellular Vesicles, variable dilution of urine is a major challenge in uEV research [76]. Whether in healthy or unwell subjects, the concentration of $\mathrm{uEV}$ is highly influenced by water-loading [77]. For this, two methods are commonly recommended to realize normalization: (1) the relative excretion rate is based on the ratio between target-marker and other markers of $\mathrm{uEV}$ (e.g., numbers, the total yield of protein or RNA, tetraspanin, prostate-specific markers, etc.); (2) the absolute excretion rate is based on a long-term collection of urine or the ratio between target-marker and urinary creatinine [76].

2. The measurement of markers in uEV mostly depends on isolation. This could cause bias, especially loss or selection of uEV due to diverse methods, e.g., ultracentrifugation, size exclusion chromatography, precipitation [78-80]. More efforts are still needed to compare the yield and purity of $\mathrm{uEV}$ between techniques. To avoid isolation bias, more sensitive techniques, such as imaging flow cytometry, might provide the possibility of independence of isolation, also facilitating the detection of a particular population of uEV [81], especially the donor-specific HLA-positive uEV [78]. Analysis of subpopulations of uEVs will reveal their specific contribution in clinical events by zooming in on uEV subpopulations; their role in rejection and other complications after transplantation will then become evident. This improves the value of $\mathrm{uEV}$ measurements like Western blot and immunoblot analysis.

3. The data is based on small, single-center studies, which makes it difficult to draw conclusions. Future studies should take a multi-center approach which enables large patient numbers. This should take into account clinical properties including (1) gender, race, age, body size, HLA-mismatch, and common chronic diseases (e.g., hypertension, diabetes mellitus, and hepatitis virus infection) of donor and recipient; (2) the type and proportion of donors, e.g., living donor or deceased donor; (3) immunosuppressortreated or -free, and the type of medicine administered. This information is of critical value for multivariate analysis, which will provide results defining the diagnostic accuracy of $\mathrm{uEV}$ measurement in kidney transplantation.

\section{Conclusions}

This review highlights potential $\mathrm{uEV-marker} \mathrm{candidates} \mathrm{and} \mathrm{indicates} \mathrm{directions} \mathrm{for}$ further study, opening up an attractive perspective that would universally utilize uEV in clinical practice and avoid unnecessary biopsy after kidney transplantation. Both uEV surface markers and cargos provide an abundance of information regarding the health of renal parenchymal cells and the immune response towards the kidney allograft. As a representative type of liquid biopsy, $\mathrm{uEV}$ might also be widely used in other diseases in the future.

Supplementary Materials: The following are available online at https: / www.mdpi.com/article / 10.3390/ijms221910499/s1, Table S1: Assessment of reference according to the STROBE statement. 
Author Contributions: Conceptualization, L.W. and C.C.B.; methodology, S.U. and L.W.; software, L.W.; validation, K.B., D.A.H. and C.C.B.; formal analysis, L.W.; investigation, L.W.; resources, C.C.B.; data curation, L.W.; writing-original draft preparation, L.W.; writing-review and editing, K.B., W.W.W., D.A.H. and C.C.B.; visualization, L.W.; supervision, K.B., D.A.H. and C.C.B.; project administration, C.C.B.; funding acquisition, C.C.B. All authors have read and agreed to the published version of the manuscript.

Funding: This review was funded by China Scholarship Council, grant number 202008430154.

Institutional Review Board Statement: Not applicable.

Informed Consent Statement: Not applicable.

Data Availability Statement: Not applicable.

Conflicts of Interest: D.A. Hesselink has received lecture fees and consulting fees from Astellas Pharma, Chiesi Pharma, Medincell, Novartis Pharma, and Vifor Pharma. He has received grant support from Astellas Pharma, Bristol-Myers Squibb, and Chiesi Pharma [paid to his institution]. D.A. Hesselink does not have employment or stock ownership at any of these companies, and neither does he have patents or patent applications. Other authors declare no conflict of interest.

\section{References}

1. Axelrod, D.A.; Schnitzler, M.A.; Xiao, H.; Irish, W.; Tuttle-Newhall, E.; Chang, S.H.; Kasiske, B.L.; Alhamad, T.; Lentine, K.L. An Economic Assessment of Contemporary Kidney Transplant Practice. Am. J. Transplant. 2018, 18, 1168-1176. [CrossRef]

2. Hart, A.; Smith, J.M.; Skeans, M.A.; Gustafson, S.K.; Wilk, A.R.; Castro, S.; Foutz, J.; Wainright, J.L.; Snyder, J.J.; Kasiske, B.L.; et al. OPTN/SRTR 2018 Annual Data Report: Kidney. Am. J. Transplant. 2020, 20, 20-130. [CrossRef]

3. Kramer, A.; Boenink, R.; Noordzij, M.; Bosdriesz, J.R.; Stel, V.S.; Beltrán, P.; Ruiz, J.C.; Seyahi, N.; Comas Farnés, J.; Stendahl, M.; et al. The ERA-EDTA Registry Annual Report 2017: A Summary. Clin. Kidney J. 2020, 13, 693-709. [CrossRef]

4. Gielis, E.M.; Beirnaert, C.; Dendooven, A.; Meysman, P.; Laukens, K.; De Schrijver, J.; Van Laecke, S.; Van Biesen, W.; Emonds, M.P.; De Winter, B.Y.; et al. Plasma Donor-Derived Cell-Free DNA Kinetics after Kidney Transplantation Using a Single Tube Multiplex PCR Assay. PLoS ONE 2018, 13, e0208207. [CrossRef]

5. Goldberg, R.J.; Weng, F.L.; Kandula, P. Acute and Chronic Allograft Dysfunction in Kidney Transplant Recipients. Med. Clin. N. Am. 2016, 100, 487-503. [CrossRef]

6. Théry, C.; Witwer, K.W.; Aikawa, E.; Alcaraz, M.J.; Anderson, J.D.; Andriantsitohaina, R.; Antoniou, A.; Arab, T.; Archer, F.; Atkin-Smith, G.K.; et al. Minimal Information for Studies of Extracellular Vesicles 2018 (MISEV2018): A Position Statement of the International Society for Extracellular Vesicles and Update of the MISEV2014 Guidelines. J. Extracell. Vesicles 2018, 7, 2001-3078. [CrossRef]

7. Găman, M.-A.; Cozma, M.-A.; Dobrică, E.-C.; Crețoiu, S.M.; Găman, A.M.; Diaconu, C.C. Liquid Biopsy and Potential Liquid Biopsy-Based Biomarkers in Philadelphia-Negative Classical Myeloproliferative Neoplasms: A Systematic Review. Life 2021, 11, 677. [CrossRef]

8. Fekih, R.E.; Hurley, J.; Tadigotla, V.; Alghamdi, A.; Srivastava, A.; Coticchia, C.; Choi, J.; Allos, H.; Yatim, K.; Alhaddad, A.; et al. Discovery and Validation of a Urinary Exosome MRNA Signature for the Diagnosis of Human Kidney Transplant Rejection. J. Am. Soc. Nephrol. 2021, 32, 994-1004. [CrossRef]

9. Santucci, L.; Bruschi, M.; Del Zotto, G.; Antonini, F.; Ghiggeri, G.M.; Panfoli, I.; Candiano, G. Biological Surface Properties in Extracellular Vesicles and Their Effect on Cargo Proteins. Sci. Rep. 2019, 9, 13048. [CrossRef]

10. Battistelli, M.; Falcieri, E. Apoptotic Bodies: Particular Extracellular Vesicles Involved in Intercellular Communication. Biology 2020, 9, 21. [CrossRef]

11. Kalluri, R.; LeBleu, V.S. The Biology, Function, and Biomedical Applications of Exosomes. Science 2020, 367, 30. [CrossRef]

12. Svenningsen, P.; Sabaratnam, R.; Jensen, B.L. Urinary Extracellular Vesicles: Origin, Role as Intercellular Messengers and Biomarkers; Efficient Sorting and Potential Treatment Options. Acta Physiol. 2020, 228, e13346. [CrossRef] [PubMed]

13. Wu, Q.; Poulsen, S.; Murali, S.; Grimm, P.R.; Su, X.-T.; Delpire, E.; Welling, P.; Ellison, D.; Fenton, R. Large-Scale Proteomic Assessment of Urinary Extracellular Vesicles Highlights Their Reliability in Reflecting Protein Changes in the Kidney. J. Am. Soc. Nephrol. 2021, 32, 2195-2209. [CrossRef]

14. Page, M.J.; McKenzie, J.E.; Bossuyt, P.M.; Boutron, I.; Hoffmann, T.C.; Mulrow, C.D.; Shamseer, L.; Tetzlaff, J.M.; Akl, E.A.; Brennan, S.E.; et al. The PRISMA 2020 Statement: An Updated Guideline for Reporting Systematic Reviews. BMJ 2021, 372 , n71. [CrossRef]

15. von Elm, E.; Altman, D.G.; Egger, M.; Pocock, S.J.; Gøtzsche, P.C.; Vandenbroucke, J.P. The Strengthening the Reporting of Observational Studies in Epidemiology (STROBE) Statement: Guidelines for Reporting Observational Studies. Lancet 2007, 370 , 1453-1457. [CrossRef] 
16. Sonoda, H.; Yokota-Ikeda, N.; Oshikawa, S.; Kanno, Y.; Yoshinaga, K.; Uchida, K.; Ueda, Y.; Kimiya, K.; Uezono, S.; Ueda, A.; et al. Decreased Abundance of Urinary Exosomal Aquaporin-1 in Renal Ischemia-Reperfusion Injury. Am. J. Physiol.-Ren. Physiol. 2009, 297, F1006-F1016. [CrossRef]

17. Pisitkun, T.; Gandolfo, M.T.; Das, S.; Knepper, M.A.; Bagnasco, S.M. Application of Systems Biology Principles to Protein Biomarker Discovery: Urinary Exosomal Proteome in Renal Transplantation. Proteom.-Clin. Appl. 2012, 6, 268-278. [CrossRef]

18. Alvarez, S.; Suazo, C.; Boltansky, A.; Ursu, M.; Carvajal, D.; Innocenti, G.; Vukusich, A.; Hurtado, M.; Villanueva, S.; Carreño, J.E.; et al. Urinary Exosomes as a Source of Kidney Dysfunction Biomarker in Renal Transplantation. Transplant. Proc. 2013, 45, 3719-3723. [CrossRef] [PubMed]

19. Dimuccio, V.; Ranghino, A.; Barbato, L.P.; Fop, F.; Biancone, L.; Camussi, G.; Bussolati, B. Urinary CD133+ Extracellular Vesicles Are Decreased in Kidney Transplanted Patients with Slow Graft Function and Vascular Damage. PLoS ONE 2014, 9, e104490. [CrossRef] [PubMed]

20. Esteva-Font, C.; Guillén-Gómez, E.; Diaz, J.M.; Guirado, L.; Facundo, C.; Ars, E.; Ballarin, J.A.; Fernández-Llama, P. Renal Sodium Transporters Are Increased in Urinary Exosomes of Cyclosporine-Treated Kidney Transplant Patients. Am. J. Nephrol. 2014, 39, 528-535. [CrossRef] [PubMed]

21. Sigdel, T.K.; Ng, Y.W.; Lee, S.; Nicora, C.D.; Qian, W.J.; Smith, R.D.; Camp, D.G.; Sarwal, M.M. Perturbations in the Urinary Exosome in Transplant Rejection. Front. Med. 2015, 2, 57. [CrossRef]

22. Kim, M.H.; Lee, Y.H.; Seo, J.W.; Moon, H.; Kim, J.S.; Kim, Y.G.Y.H.; Jeong, K.H.; Moon, J.Y.; Lee, T.W.; Ihm, C.G.; et al. Urinary Exosomal Viral MicroRNA as a Marker of BK Virus Nephropathy in Kidney Transplant Recipients. PLoS ONE 2017, 12, e0190068. [CrossRef]

23. Park, J.; Lin, H.-Y.Y.; Assaker, J.P.; Jeong, S.; Huang, C.-H.H.; Kurdi, A.; Lee, K.; Fraser, K.; Min, C.; Eskandari, S.; et al. Integrated Kidney Exosome Analysis for the Detection of Kidney Transplant Rejection. ACS Nano 2017, 11, 11041-11046. [CrossRef]

24. Tutakhel, O.A.Z.; Moes, A.D.; Valdez-Flores, M.A.; Kortenoeven, M.L.A.; Vrie, M.V.D.; Jelen, S.; Fenton, R.A.; Zietse, R.; Hoenderop, J.G.J.; Hoorn, E.J.; et al. NaCl Cotransporter Abundance in Urinary Vesicles Is Increased by Calcineurin Inhibitors and Predicts Thiazide Sensitivity. PLoS ONE 2017, 12, e0176220. [CrossRef]

25. Hinrichs, G.R.; Michelsen, J.S.; Zachar, R.; Friis, U.G.; Svenningsen, P.; Birn, H.; Bistrup, C.; Jensen, B.L. Albuminuria in Kidney Transplant Recipients Is Associated with Increased Urinary Serine Proteases and Activation of the Epithelial Sodium Channel. Am. J. Physiol.-Ren. Physiol. 2018, 315, F151-F160. [CrossRef] [PubMed]

26. Lim, J.H.; Lee, C.H.; Kim, K.Y.; Jung, H.Y.; Choi, J.Y.; Cho, J.H.; Park, S.H.; Kim, Y.L.; Baek, M.C.; Park, J.B.; et al. Novel Urinary Exosomal Biomarkers of Acute T Cell-Mediated Rejection in Kidney Transplant Recipients: A Cross-Sectional Study. PLoS ONE 2018, 13, e0204204. [CrossRef] [PubMed]

27. Carreras-Planella, L.; Juega, J.; Taco, O.; Cañas, L.; Franquesa, M.; Lauzurica, R.; Borràs, F.E. Proteomic Characterization of Urinary Extracellular Vesicles from Kidney-Transplanted Patients Treated with Calcineurin Inhibitors. Int. J. Mol. Sci. 2020, 21, 7569. [CrossRef] [PubMed]

28. Jung, H.Y.; Lee, C.H.; Choi, J.Y.; Cho, J.H.; Park, S.H.; Kim, Y.L.; Moon, P.G.; Baek, M.C.; Berm Park, J.; Hoon Kim, Y.; et al. Potential Urinary Extracellular Vesicle Protein Biomarkers of Chronic Active Antibody-Mediated Rejection in Kidney Transplant Recipients. J. Chromatogr. B Anal. Technol. Biomed. Life Sci. 2020, 1138, 121958. [CrossRef] [PubMed]

29. Takada, Y.; Kamimura, D.; Jiang, J.J.; Higuchi, H.; Iwami, D.; Hotta, K.; Tanaka, Y.; Ota, M.; Higuchi, M.; Nishio, S.; et al. Increased Urinary Exosomal SYT17 Levels in Chronic Active Antibody-Mediated Rejection after Kidney Transplantation via the IL-6 Amplifier. Int. Immunol. 2020, 32, 653-662. [CrossRef]

30. Liu, Y.; Li, S.; Rong, W.; Zeng, C.; Zhu, X.; Chen, Q.; Li, L.; Liu, Z.-H.; Zen, K. Podocyte-Released Migrasomes in Urine Serve as an Indicator for Early Podocyte Injury. Kidney Dis. 2020, 6, 422-433. [CrossRef]

31. Medeiros, T.; Myette, R.L.; Almeida, J.R.; Silva, A.A.; Burger, D. Extracellular Vesicles: Cell-Derived Biomarkers of Glomerular and Tubular Injury. Cell. Physiol. Biochem. 2020, 54, 88-109. [CrossRef]

32. Turco, A.E.; Lam, W.; Rule, A.D.; Denic, A.; Lieske, J.C.; Miller, V.M.; Larson, J.J.; Kremers, W.K.; Jayachandran, M. Specific Renal Parenchymal-Derived Urinary Extracellular Vesicles Identify Age-Associated Structural Changes in Living Donor Kidneys. J. Extracell. Vesicles 2016, 5, 29642. [CrossRef]

33. Karpman, D.; Tontanahal, A. Extracellular Vesicles in Renal Inflammatory and Infectious Diseases. Sci. Total Environ. 2019, $171,135907$.

34. Benichou, G.; Wang, M.; Ahrens, K.; Madsen, J.C. Extracellular Vesicles in Allograft Rejection and Tolerance. Cell. Immunol. 2020, 349, 104063. [CrossRef]

35. Urbanelli, L.; Buratta, S.; Tancini, B.; Sagini, K.; Delo, F.; Porcellati, S.; Emiliani, C. The Role of Extracellular Vesicles in Viral Infection and Transmission. Vaccines 2019, 7, 102. [CrossRef] [PubMed]

36. Pisitkun, T.; Shen, R.F.; Knepper, M.A. Identification and Proteomic Profiling of Exosomes in Human Urine. Proc. Natl. Acad. Sci. USA. 2004, 101, 13368-13373. [CrossRef] [PubMed]

37. Braun, F.; Rinschen, M.; Buchner, D.; Bohl, K.; Plagmann, I.; Bachurski, D.; Richard Späth, M.; Antczak, P.; Göbel, H.; Klein, C.; et al. The Proteomic Landscape of Small Urinary Extracellular Vesicles during Kidney Transplantation. J. Extracell. Vesicles 2020, 10, e12026. [CrossRef]

38. Oshikawa-Hori, S.; Yokota-Ikeda, N.; Sonoda, H.; Sasaki, Y.; Ikeda, M. Reduced Urinary Release of AQP1- and AQP2-bearing Extracellular Vesicles in Patients with Advanced Chronic Kidney Disease. Physiol. Rep. 2021, 9, e15005. [CrossRef] 
39. Oshikawa-Hori, S.; Yokota-Ikeda, N.; Sonoda, H.; Ikeda, M. Urinary Extracellular Vesicular Release of Aquaporins in Patients with Renal Transplantation. BMC Nephrol. 2019, 20, 216. [CrossRef] [PubMed]

40. Sagrinati, C.; Netti, G.S.; Mazzinghi, B.; Lazzeri, E.; Liotta, F.; Frosali, F.; Ronconi, E.; Meini, C.; Gacci, M.; Squecco, R.; et al. Isolation and Characterization of Multipotent Progenitor Cells from the Bowman's Capsule of Adult Human Kidneys. J. Am. Soc. Nephrol. 2006, 17, 2443-2456. [CrossRef] [PubMed]

41. Gonzales, P.A.; Pisitkun, T.; Hoffert, J.D.; Tchapyjnikov, D.; Star, R.A.; Kleta, R.; Wang, N.S.; Knepper, M.A. Large-Scale Proteomics and Phosphoproteomics of Urinary Exosomes. J. Am. Soc. Nephrol. 2009, 20, 363-379. [CrossRef]

42. Prunotto, M.; Farina, A.; Lane, L.; Pernin, A.; Schifferli, J.; Hochstrasser, D.F.; Lescuyer, P.; Moll, S. Proteomic Analysis of Podocyte Exosome-Enriched Fraction from Normal Human Urine. J. Proteom. 2013, 82, 193-229. [CrossRef] [PubMed]

43. Schütz, E.; Fischer, A.; Beck, J.; Harden, M.; Koch, M.; Wuensch, T.; Stockmann, M.; Nashan, B.; Kollmar, O.; Matthaei, J.; et al. Donor-Derived Cell-Free DNA Is a Novel Universal Biomarker for Allograft Rejection in Solid Organ Transplantation. Am. J. Transplant. 2019, 19, 108-112.

44. Verhoeven, J.G.H.P.; Boer, K.; Van Schaik, R.H.N.; Manintveld, O.C.; Huibers, M.M.H.; Baan, C.C.; Hesselink, D.A. Liquid Biopsies to Monitor Solid Organ Transplant Function. Ther. Drug Monit. 2018, 40, 515-525. [CrossRef]

45. Verhoeven, J.G.H.P.; Peeters, A.M.A.; Hesselink, D.A.; Boer, K. Pitfalls in the Detection of Donor-Derived Cell-Free DNA in Transplant Recipients. Clin. Chem. 2021, 67, 1030-1032. [CrossRef]

46. Knight, S.R.; Thorne, A.; Lo Faro, M.L. Donor-Specific Cell-Free DNA as a Biomarker in Solid Organ Transplantation. A Systematic Review. Transplantation 2019, 103, 273-283. [CrossRef] [PubMed]

47. Cossarizza, A.; Chang, H.D.; Radbruch, A.; Akdis, M.; Andrä, I.; Annunziato, F.; Bacher, P.; Barnaba, V.; Battistini, L.; Bauer, W.M.; et al. Guidelines for the Use of Flow Cytometry and Cell Sorting in Immunological Studies. Eur. J. Immunol. 2017, 47, 1584-1797. [CrossRef] [PubMed]

48. Guescini, M.; Genedani, S.; Stocchi, V.; Agnati, L.F. Astrocytes and Glioblastoma Cells Release Exosomes Carrying MtDNA. J. Neural Transm. 2010, 117, 1. [CrossRef]

49. Kalluri, R.; Lebleu, V.S. Discovery of Double-Stranded Genomic DNA in Circulating Exosomes. Cold Spring Harb. Symp. Quant. Biol. 2016, 81, 275-280. [CrossRef] [PubMed]

50. Fernando, M.R.; Jiang, C.; Krzyzanowski, G.D.; Ryan, W.L. New Evidence That a Large Proportion of Human Blood Plasma Cell-Free DNA Is Localized in Exosomes. PLoS ONE 2017, 12, e0183915. [CrossRef]

51. Sigdel, T.K.; Vitalone, M.J.; Tran, T.Q.; Dai, H.; Hsieh, S.C.; Salvatierra, O.; Sarwal, M.M. A Rapid Noninvasive Assay for the Detection of Renal Transplant Injury. Transplantation 2013, 96, 97-101. [CrossRef]

52. Coemans, M.; Van Loon, E.; Lerut, E.; Gillard, P.; Sprangers, B.; Senev, A.; Emonds, M.P.; Van Keer, J.; Callemeyn, J.; Daniëls, L.; et al. Occurrence of Diabetic Nephropathy after Renal Transplantation despite Intensive Glycemic Control: An Observational Cohort Study. Diabetes Care 2019, 42, 625-634. [CrossRef] [PubMed]

53. Sharma, K.; Karl, B.; Mathew, A.V.; Gangoiti, J.A.; Wassel, C.L.; Saito, R.; Pu, M.; Sharma, S.; You, Y.-H.; Wang, L.; et al. Metabolomics Reveals Signature of Mitochondrial Dysfunction in Diabetic Kidney Disease. J. Am. Soc. Nephrol. 2013, 24, 1901-1912. [CrossRef] [PubMed]

54. Wei, P.Z.; Kwan, B.C.H.; Chow, K.M.; Cheng, P.M.S.; Luk, C.C.W.; Li, P.K.T.; Szeto, C.C. Urinary Mitochondrial DNA Level Is an Indicator of Intra-Renal Mitochondrial Depletion and Renal Scarring in Diabetic Nephropathy. Nephrol. Dial. Transplant. 2018, 33 , 784-788. [CrossRef] [PubMed]

55. Salvia, S.L.; Musante, L.; Lannigan, J.; Gigliotti, J.C.; Le, T.H.; Erdbrugger, U. T-Cell Derived Extracellular Vesicles Are Elevated in Essential HTN. Am. J. Physiol.-Ren. Physiol. 2020, 319, F868-F875. [CrossRef] [PubMed]

56. Feng, Y.; Zhong, X.; Ni, H.F.; Wang, C.; Tang, T.T.; Wang, L.T.; Song, K.Y.; Tang, R.N.; Liu, H.; Liu, B.C.; et al. Urinary Small Extracellular Vesicles Derived CCL21 MRNA as Biomarker Linked with Pathogenesis for Diabetic Nephropathy. J. Transl. Med. 2021, 19, 355. [CrossRef] [PubMed]

57. Cheng, L.; Sun, X.; Scicluna, B.J.; Coleman, B.M.; Hill, A.F. Characterization and Deep Sequencing Analysis of Exosomal and Non-Exosomal MiRNA in Human Urine. Kidney Int. 2014, 86, 433-444. [CrossRef] [PubMed]

58. Crescitelli, R.; Lässer, C.; Szabó, T.G.; Kittel, A.; Eldh, M.; Dianzani, I.; Buzás, E.I.; Lötvall, J. Distinct RNA Profiles in Subpopulations of Extracellular Vesicles: Apoptotic Bodies, Microvesicles and Exosomes. J. Extracell. Vesicles 2013, 2, 20677. [CrossRef]

59. Yu, Y.; Bai, F.; Qin, N.; Liu, W.; Sun, Q.; Zhou, Y.; Yang, J. Non-Proximal Renal Tubule-Derived Urinary Exosomal MiR-200b as a Biomarker of Renal Fibrosis. Nephron 2018, 139, 269-282. [CrossRef]

60. Franco-Acevedo, A.; Melo, Z.; Echavarria, R. Diagnostic, Prognostic, and Therapeutic Value of Non-Coding RNA Expression Profiles in Renal Transplantation. Diagnostics 2020, 10, 60. [CrossRef]

61. Gildea, J.J.; Carlson, J.M.; Schoeffel, C.D.; Carey, R.M.; Felder, R.A. Urinary Exosome MiRNome Analysis and Its Applications to Salt Sensitivity of Blood Pressure. Clin. Biochem. 2013, 46, 1131-1134. [CrossRef]

62. Lozano-Ramos, S.I.; Bancu, I.; Carreras-Planella, L.; Monguió-Tortajada, M.; Cañas, L.; Juega, J.; Bonet, J.; Armengol, M.P.; Lauzurica, R.; Borràs, F.E. Molecular Profile of Urine Extracellular Vesicles from Normo-Functional Kidneys Reveal Minimal Differences between Living and Deceased Donors. BMC Nephrol. 2018, 19, 189. [CrossRef]

63. Zheng, S.B.; Zheng, Y.; Jin, L.W.; Zhou, Z.H.; Li, Z.Y. Microvesicles Containing MicroRNA-21 Secreted by Proximal Tubular Epithelial Cells Are Involved in Renal Interstitial Fibrosis by Activating AKT Pathway. Eur. Rev. Med. Pharmacol. Sci. 2018, 22, 707-714. 
64. Sonoda, H.; Lee, B.R.; Park, K.H.; Nihalani, D.; Yoon, J.H.; Ikeda, M.; Kwon, S.H. MiRNA Profiling of Urinary Exosomes to Assess the Progression of Acute Kidney Injury. Sci. Rep. 2019, 9, 4692. [CrossRef]

65. Gniewkiewicz, M.S.; Paszkowska, I.; Gozdowska, J.; Czerwinska, K.; Sadowska-Jakubowicz, A.; Deborska-Materkowska, D.; Perkowska-Ptasinska, A.; Kosieradzki, M.; Durlik, M. Urinary MicroRNA-21-5p as Potential Biomarker of Interstitial Fibrosis and Tubular Atrophy (IFTA) in Kidney Transplant Recipients. Diagnostics 2020, 10, 113. [CrossRef] [PubMed]

66. Khalid, U.; Newbury, L.J.; Simpson, K.; Jenkins, R.H.; Bowen, T.; Bates, L.; Sheerin, N.S.; Chavez, R.; Fraser, D.J. A Urinary MicroRNA Panel That Is an Early Predictive Biomarker of Delayed Graft Function Following Kidney Transplantation. Sci. Rep. 2019, 9, 3584. [CrossRef]

67. Zununi Vahed, S.; Omidi, Y.; Ardalan, M.; Samadi, N. Dysregulation of Urinary MiR-21 and MiR-200b Associated with Interstitial Fibrosis and Tubular Atrophy (IFTA) in Renal Transplant Recipients. Clin. Biochem. 2017, 50, 32-39. [CrossRef] [PubMed]

68. Lorenzen, J.M.; Volkmann, I.; Fiedler, J.; Schmidt, M.; Scheffner, I.; Haller, H.; Gwinner, W.; Thum, T. Urinary MiR-210 as a Mediator of Acute T-Cell Mediated Rejection in Renal Allograft Recipients. Am. J. Transplant. 2011, 11, 2221-2227. [CrossRef]

69. Funahashi, Y. BK Virus-Associated Nephropathy after Renal Transplantation. Pathogens 2021, 10, 150. [CrossRef]

70. Huang, Y.; Zeng, G.; Randhawa, P.S. Detection of BKV Encoded Mature MicroRNAs in Kidney Transplant Patients: Clinical and Biologic Insights. J. Clin. Virol. 2019, 119, 6-10. [CrossRef] [PubMed]

71. Akalin, E.; Azzi, Y.; Bartash, R.; Seethamraju, H.; Parides, M.; Hemmige, V.; Ross, M.; Forest, S.; Goldstein, Y.D.; Ajaimy, M.; et al. Covid-19 and Kidney Transplantation. N. Engl. J. Med. 2020, 382, 2475-2477. [CrossRef]

72. Banerjee, D.; Popoola, J.; Shah, S.; Ster, I.C.; Quan, V.; Phanish, M. COVID-19 Infection in Kidney Transplant Recipients. Kidney Int. 2020, 97, 1076-1082. [CrossRef]

73. Braun, F.; Lütgehetmann, M.; Pfefferle, S.; Wong, M.N.; Carsten, A.; Lindenmeyer, M.T.; Nörz, D.; Heinrich, F.; Meißner, K.; Wichmann, D.; et al. SARS-CoV-2 Renal Tropism Associates with Acute Kidney Injury. Lancet 2020, 396, 597-598. [CrossRef]

74. Wurtzer, S.; Waldman, P.; Ferrier-Rembert, A.; Frenois-Veyrat, G.; Mouchel, J.M.; Boni, M.; Maday, Y.; Marechal, V.; Moulin, L. Several Forms of SARS-CoV-2 RNA Can Be Detected in Wastewaters: Implication for Wastewater-Based Epidemiology and Risk Assessment. Water Res. 2021, 198, 117183. [CrossRef]

75. Mishra, R.; Banerjea, A.C. SARS-CoV-2 Spike Targets USP33-IRF9 Axis via Exosomal MiR-148a to Activate Human Microglia. Front. Immunol. 2021, 12, 656700. [CrossRef] [PubMed]

76. Erdbrügger, U.; Blijdorp, C.J.; Bijnsdorp, I.V.; Borràs, F.E.; Burger, D.; Bussolati, B.; Byrd, J.B.; Clayton, A.; Dear, J.W.; Juan, M.; et al. Urinary Extracellular Vesicles: A Position Paper by the Urine Task Force of the International Society for Extracellular Vesicles. J. Extracell. Vesicles 2021, 10, e12093. [CrossRef] [PubMed]

77. Blijdorp, C.J.; Tutakhel, O.A.Z.; Hartjes, T.A.; van den Bosch, T.P.P.; van Heugten, M.H.; Rigalli, J.P.; Willemsen, R.; Musterdbhaggoe, U.M.; Barros, E.R.; Carles-fontana, R.; et al. Comparing Approaches to Normalize, Quantify, and Characterize Urinary Extracellular Vesicles. J. Am. Soc. Nephrol. 2021, 32, 1210-1226. [CrossRef] [PubMed]

78. Mastoridis, S. Multiparametric Analysis of Circulating Exosomes and Other Small Extracellular Vesicles by Advanced Imaging Flow Cytometry. Front. Immunol. 2018, 9, 1583. [CrossRef]

79. Freitas, D.; Balmaña, M.; Poças, J.; Campos, D.; Osório, H.; Konstantinidi, A.; Vakhrushev, S. Different Isolation Approaches Lead to Diverse Glycosylated Extracellular Vesicle Populations. J. Extracell. Vesicles 2019, 8, 1621131. [CrossRef]

80. Liangsupree, T.; Multia, E.; Riekkola, M.L. Modern Isolation and Separation Techniques for Extracellular Vesicles. J. Chromatogr. A 2021, 1636, 461773. [CrossRef]

81. Görgens, A.; Bremer, M.; Ferrer-Tur, R.; Murke, F.; Tertel, T.; Horn, P.A.; Thalmann, S.; Welsh, J.A.; Probst, C.; Guerin, C.; et al. Optimisation of Imaging Flow Cytometry for the Analysis of Single Extracellular Vesicles by Using Fluorescence-Tagged Vesicles as Biological Reference Material. J. Extracell. Vesicles 2019, 8, 1587567. [CrossRef] [PubMed] 